\title{
ANALISIS FAKTOR YANG MEMPENGARUHI KEJADIAN MASTITIS SUBKLINIS DAN KLINIS PADA SAPI PERAH \\ (STUDI KASUS DI KOPERASI AGRIBISNIS DANA MULYA KECAMATAN \\ PACET, KABUPATEN MOJOKERTO)
}

\section{ANALYSIS OF FACTOR AFFECTING SUBCLINICAL AND CLINICAL MASTITIS IN DAIRY COW \\ (CASE STUDY IN THE COOPERATIVE AGRIBUSINESS DANA MULYA PACET, MOJOKERTO)}

\author{
Hefi Choirun Nisa ${ }^{1)}$, *Bambang Purnomo S. ${ }^{2)}$, Tita Damayanti L. ${ }^{3)}$ \\ Mas'ud Hariadi ${ }^{3)}$, Romziah Sidik ${ }^{4)}$, Nenny Harijani ${ }^{5)}$ \\ ${ }^{1)}$ Student, ${ }^{2)}$ Veterinary Anatomy Department, ${ }^{3)}$ Veterinary Reproduction Department \\ 4) Animal Husbandry Department, ${ }^{5)}$ Veterinary Public Health Department \\ Faculty of Veterinary Medicine, Universitas Airlangga \\ heficn@gmail.com; *Corresponding author: email: hajibps_2009@gmail.com
}

\begin{abstract}
The study was conducted to know the factor that potentially affect the incidence of subclinical and clinical mastitis in dairy cows in the area Agribusiness Cooperative Dana Mulya Pacet, Mojokerto. Data retrieval were done by examining the incidence of subclinical and clinical mastitis in 100 lactation dairy cows. Milk samples were taken from milking each quarter of dairy cows in the afternoon, then tested using CMT reagent (California Mastitis Test). In addition data was obtained from farmers through structured questionnaires. The data was processed and presented in tabular form and analyzed statistically by the method of regression trees. The conclusion of this research showed that dairy cows in the area of Agribusiness Cooperative Dana Mulya Pacet, Mojokerto affected by subclinical mastitis reached $76 \%$ and clinical mastitis $11 \%$. This was influenced by the milking sequence factor of the nipple which was not distinguish between sick and healthy nipples, the lack of sanitation before milking, and the location of livestock disposal is too close to the cowshed.
\end{abstract}

Keywords : dairy cows, subclinical mastitis, clinical mastitis.

\section{Pendahuluan}

Ternak sapi, khususnya sapi perah merupakan salah satu sumber daya penghasil protein berupa susu yang memiliki nilai ekonomi tinggi dan penting artinya bagi kehidupan masyarakat. Meningkatnya kesadaran masyarakat tentang nilai gizi dan kebutuhan akan protein hewani menyebabkan kebutuhan susu sapi juga ikut meningkat. Menurut Data Statistik Dinas Peternakan Provinsi Jawa Timur, populasi ternak sapi perah mengalami peningkatan yaitu 255.947 ekor dengan jumlah produksi susu 472.212.765 kg pada tahun 2015 dan jumlah populasi sapi perah 265.002 ekor dengan hasil produksi susu mencapai $492.460 .620 \mathrm{~kg}$ di tahun 2016.
Penghambat dalam peningkatan produksi susu salah satunya dipengaruhi oleh manajemen pemeliharaan sapi perah di Indonesia masih kurang dalam hal sanitasi lingkungan, sanitasi peralatan pemerahan dan air, tatacara pemerahan yang benar serta kesehatan mulai dari proses pemeliharaan sampai produksi.

Manajemen kesehatan ternak yang tidak baik merupakan ancaman besar bagi para peternak sapi perah. Salah satu ancaman penyakit yang sering menyerang sapi perah saat memproduksi susu atau laktasi dan menyebabkan kerugian ekonomi yang sangat besar bagi peternakan sapi perah diseluruh dunia ialah mastitis (Bannerman and Wall, 2005). Mastitis merupakan peradangan pada jaringan 
internal ambing atau kelenjar mammae oleh bakteri, terpapar zat kimiawi dan luka akibat mekanis (Ahmad, 2011).

Kejadian mastitis di Indonesia sangat tinggi yaitu sekitar $97-98 \%$ merupakan mastitis subklinis, sedangkan 2-3\% merupakan kasus mastitis klinis yang terdeteksi (Sudarwanto dan Sudarnika, 2008). Kondisi tersebut menyebabkan kerugian yang sangat besar terhadap peternak (Junqiang et al., 2007), yaitu berupa penurunan kualitas susu yang mengakibatkan penolakan susu oleh pengumpul, penurunan kualitas hasil olahan susu, peningkatan biaya perawatan dan pengobatan, kematian sapi, adanya residu antibiotic pada susu serta pengafkiran ternak lebih awal (Sudarwanto dan Sudarnika, 2008).

Koperasi Agribisnis Dana Mulya Kecamatan Pacet yang menjadi kawasan sentra susu di Mojokerto yang terdapat kasus mastitis dan merupakan suplier PT. Nestle. Oleh karena itu, perlu dilakukan penelitian untuk mengetahui faktor yang mempengaruhi kejadian mastitis subklinis dan klinis pada sapi perah di Koperasi Agribisnis Dana Mulya Kecamatan Pacet, Kabupaten Mojokertoto.

\section{Rumusan Masalah}

Perumusan masalah dari penelitian ini adalah faktor apa yang mempengaruhi kejadian mastitis subklinis dan klinis pada sapi perah di Koperasi Agribisnis Dana Mulya Kecamatan Pacet, Kabupaten Mojokerto?

\section{Tujuan Penelitian}

Penelitian ini bertujuan untuk mengetahui faktor yang berpotensi mempengaruhi kejadian mastitis subklinis dan klinis pada sapi perah di Koperasi Agribisnis Dana Mulya Kecamatan Pacet, Kabupaten Mojokerto agar dapat meningkatkan produksi sapi perah.

\section{Manfaat Hasil Penelitian}

Manfaat yang diperoleh dari hasil penelitian ini selain menambah pengetahuan dan wawasan bagi mahasiswa, juga diharapkan dapat menjadi bahan acuan bagi peternak dalam melakukan tindakan pencegahan pada mastitis subklinis dan klinis pada sapi perah melalui perbaikan manajemen secara menyeluruh.

\section{Metode Penelitian}

Metode penelitian menggunakan metode studi kasus dilapangan yaitu pemilihan sampel dari populasi peternak berdasarkan dengan kriteria inklusi subyek penelitian di Koperasi Agribisnis Dana Mulya Kecamatan Pacet, Kabupaten Mojokerto. Pengambilan data dilakukan dengan cara pemeriksaan mastitis pada sapi perah dengan menggunakan reagen CMT (California Mastitis Test) dan melakukan pendataan pada sapi perah yang memiliki riwayat mastitis klinis, kemudian melakukan wawancara atau teknik face-to-face interview kepada peternak sapi perah rakyat yang berpedoman pada kuisioner terstruktur.

Alat dan bahan untuk uji California Mastitis Test (CMT) adalah cawan paddle, pipet tetes, reagen CMT dan susu. CMT dilakukan dengan membuang pancaran susu yang pertama terlebih dahulu, kemudian sampel susu dari masing-masing kuartir yang akan diuji diperah langsung ke dalam Padel CMT. Sebanyak $2 \mathrm{ml}$ susu diletakkan pada padel dan ditambahkan 2 $\mathrm{ml}$ reagen CMT. Digoyangkan secara horizontal perlahan-lahan selama 10-15 detik. Setelah dilakukan pemeriksaan CMT, selanjutnya dilakukan pengamatan interpretasi tingkat mastitis (Setiawan dkk., 2012).

\section{Variabel Penelitian}

1. Variabel Independent : Faktor pakan dan air, kandang ternak, pemerahan, dan kesehatan ternak

2. Variabel Dependent : Kejadian mastitis subklinis dan klinis pada sapi perah (Tes Mastitis )

\section{Analisis Data}

Data yang diperoleh disajikan dalam bentuk tabel kemudian dianalisis secara deskriptif dan statistika meng-gunakan bantuan program software SPSS 20 (Statistic Product and Service Solution) dengan metode regresi pohon.

\section{Hasil dan Pembahasan \\ Pemeriksaan Mastitis}

Pemeriksaan terhadap mastitis baik mastitis subklinis dan klinis pada 100 ekor sapi perah laktasi di peternakan sapi perah rakyat daerah Koperasi Agribisnis Dana 
Mulya Kecamatan Pacet, Kabupaten Mojokerto memberikan hasil yaitu 76 ekor sapi perah positif mastitis subklinis, 11 ekor sapi riwayat mastitis klinis, dan 13 ekor sapi normal (negative mastitis). Menurut Sani et al., (2012) pada era tahun 19841994 prevalensi mastitis subklinis di beberapa peternakan sapi perah di Pulau Jawa jauh lebih tinggi dibandingkan dengan mastitis klinis, dimana prevalensi mastisis subklinis $37-67 \%$, sementara mastitis klinis berkisar antara $5-30 \%$. Penularan mastitis biasa terjadi dari seekor sapi ke sapi lain dan dari kuartir terinfeksi ke kuartir normal melalui tangan pemerah, kain pembersih, mesin pemerah dan lalat (Nurhayati dan Martindah, 2015). Proses infeksi mastitis subklinis dimulai dengan masuknya bakteri yang didominasi Staphylococcus aureus, Streptococcus agalactiae, Streptococcus dysgalactiae, Streptococcus uberis, Escherichia coli, beberapa jenis kapang, khamir dan virus ke dalam kelenjar melalui lubang puting yang terbuka setelah proses pemerahan (Marogna et al., 2010).

Pemeriksaan mastitis subklinis dengan menggunakan reagen CMT yang memiliki tingkat sensitivitas dan spesifisitas cukup tinggi. Menurut hasil penelitian Setiawan dkk., (2012), reagen CMT memiliki sensitivitas sebesar $96,7 \%$ dan memiliki spesifisitas sebesar $100 \%$. Hal tersebut disebabkan kandungan reagen CMT mengandung anionik surfaktan (deterjen) yang digunakan untuk mendeteksi peningkatan kadar sel somatis dalam susu mastitis. Menurut (Xia, 2006), jenis surfaktan yang berbeda memiliki efek yang berbeda pula pada susu dimana CMT mengandung Aril sulfonat alkil (3\%) dan natrium hidroksida $(1,5 \%)$ dan bromocresol purple sebagai indikator warna yang memudahkan dalam pengamatan reaksi. Sampel susu yang direaksikan dengan CMT akan ada tidaknya perubahan pada kekentalan susu, kemudian ditentukan berdasarkan skoring CMT yaitu (-) tidak ada pengendapan pada susu artinya susu berkualitas baik, (+) terdapat sedikit pengendapan pada susu artinya susu berkualitas cukup baik, (++) terdapat pengendapan yang jelas namun gel belum terbentuk artinya susu berkualitas cukup baik, (+++) campuran menebal dan mulai terbentuk gel artinya berkualitas jelek, serta
$(++++)$ gel yang terbentuk menyebabkan permukaan menjadi cembung artinya susu berkualitas sangat jelek. Pembentukan gel pada susu penderita mastitis dikarenakan rusaknya membran sel sehingga dapat menyebabkan keluarnya DNA dari inti sel kemudian surfaktan akan mendenaturasi histon yang mengikat DNA, maka terjadi peningkatan viskositas susu/DNA/surfaktan yang menjadikan susu akan terlihat lebih kental (terbentuk gel) (Xia, 2006). Sebagaimana disajikan pada Gambar 1.

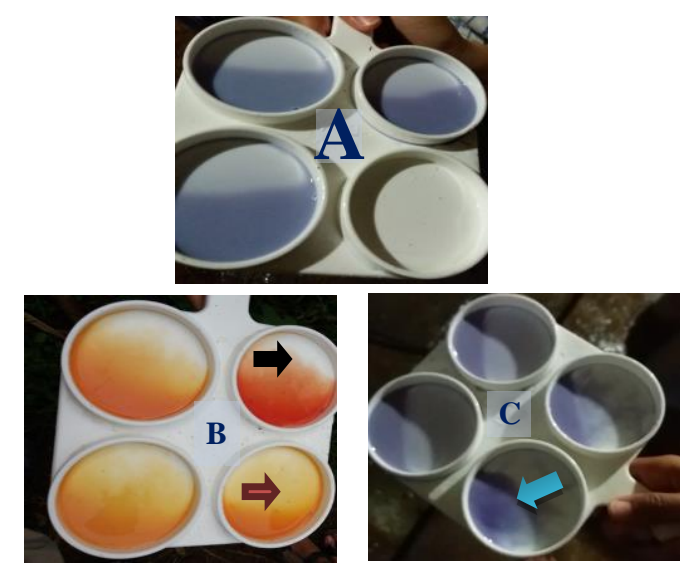

Gambar 1. Susu sapi perah setelah direaksikan dengan reagen IPB-1 dan CMT. Keterangan: A) Susu normal (negative mastitis) menggunakan IPB-1. B) Pada panah berwarna merah susu mastitis +, sedangkan pada panah berwarna hitam susu mastitis ++ menggunakan CMT. C) Pada panah berwarna biru menunjukkan susu mastitis +++ menggunakan IPB-1.

\section{Faktor yang Mempengaruhi Kejadian Mastitis Subklinis dan Klinis}

Berdasarkan hasil penelitian diperoleh bahwa $96 \%$ peternak melakukan pemerahan secara acak pada puting sapi perah, sedangkan $4 \%$ peternak memerah susu dari puting sehat ke puting yang sakit. Pemerahan yang baik adalah memerah sapi dari puting yang sehat ke sakit, agar tidak terjadi infeksi silang dari puting sakit ke sehat yang menyebabkan puting sehat menjadi sakit (Rohmah, 2012). Menurut Surjowardojo (2012) puting yang tidak dibersihkan setelah pemerahan serta pemerahan puting yang tidak terinfeksi dan yang terinfeksi tidak dibedakan dan puting yang terinfeksi terkadang dilakukan 
pemerahan terlebih dahulu, hal tersebut dapat menjadi penyebab tertularnya mastitis ke ternak yang sehat melalui tangan pemerah. Handayani dan Purwanti (2010) menyatakan bahwa tangan pemerah merupakan salah satu sumber kontaminasi bakteri dalam susu, dengan ditemukannya bakteri pathogen seperti Staphylococcus aureus (S. aureus) dan Escherichia coli (E. coli).

Sebelum pemerahan terlebih dahulu sapi dibersihkan dengan cara sapi dimandikan. Peternak sebanyak 65\% memandikan sapinya dua kali sehari. Kebiasaan memandikan sapi dua kali sehari akan menjamin kebersihan sapi dalam saat pemerahan. Kotoran-kotoran yang berasal dari alas kandang, tanah, feses, yang biasa melekat pada tubuh sapi. Selama proses pemerahan akan jatuh dari perut, ekor, lipat paha, dan ambing sapi ke dalam ember susu, sehingga dapat mengotori sekaligus mencemari susu.

Letak pembuangan limbah juga berperan terhadap timbulnya penyakit pada sapi perah, misalnya mastitis. Peternak (59\%) membuang limbah tidak jauh dari kandang peternakannya (< 15 meter). Kotoran ternak dibuang dengan menimbunnya di atas permukaan tanah atau open dumping yang digunakan sebagai pupuk kandang serta biogas yang terletak tidak jauh dari kandang. Jarak yang terlalu dekat antara tempat pembuangan limbah dengan kandang akan menyebabkan lingkungan kandang menjadi kotor, dan dapat menimbulkan pencemaran lingkungan. Hal ini akan menyebabkan bakteri tumbuh subur dan bermigrasi ke kandang sehingga setiap saat dapat menimbulkan kejadian mastitis subklinis. Tumpukan limbah peternakan akibat kondisi saluran pembuangan yang tidak baik atau tidak lancar akan menyebabkan gangguan terhadap lingkungan antara lain berupa bau busuk dan berkembangnya serangga (Winata, 2011).

Jadi, berdasarkan analisis regresi pohon menunjukkan adanya pengaruh risiko, artinya faktor-faktor tersebut dapat berpengaruh signifikan terhadap kejadian mastitis subklinis dan klinis di Koperasi Agribisnis Dana Mulya Kecamatan Pacet, Kabupaten Mojokerto.

\section{Kesimpulan}

Berdasarkan penelitian ini diperoleh kesimpulan bahwa sapi perah di peternakan wilayah Koperasi Agribisnis Dana Mulya Kecamatan Pacet, Kabupaten Mojokerto terdapat kejadian mastitis subklinis mencapai $76 \%$ dan mastitis klinis $11 \%$. Kejadian mastitis subklinis yang tinggi tersebut dipengaruhi oleh faktor urutan pemerahan pada puting sapi yang tidak dibedakan antara yang sakit dan yang sehat, kurangnya peternak dalam menjaga kebersihan sapi sebelum pemerahan dan pembuangan kotoran ternak yang terlalu dekat dengan kandang.

\section{Daftar Pustaka}

Ahmad, R.Z., 2011. Mastitis Mikotik Di Indonesia. Seminar Nasional Teknologi Peternakan dan Veteriner, (30), pp.403-410.

Bannerman, D.D. and R.J. Wall. 2005. A Novel Strategy for the Prevention of Staphylococcus aureus-Induce Mastitis in Dairy Cows. Information Systems of Biotechnology News Report. Virginia Tech University. USA.1-4.11.

Dinas Peternakan Provinsi Jawa Timur. 2017. Data Statistik Populasi dan Produksi Ternak 2015-2016. [terhubung berkala]. http://www.disnak.jatimprov.go.id [15 Juni 2017].

Handayani K.S. dan M. Purwanti. 2010. Kesehatan ambing dan higiene pemerahan di peternakan sapi perah desa Pasir Buncir, kecamatan Caringin. J. Penyuluh Per. 5(1):47-54.

Junqiang, W., Songhua Hu, and Liting Cao. 2007. Therapeutic Effect of Nisin Z on Subclinical Mastitis in Lactating Cows. Antimicrobial Agents and Chemotherapy. 51(9): 3131-3135.

Marogna G., S. Rolesu, S. Lollai, S. Tola, and G. Leori. 2010. Clinical findings in sheep farms affected by recurrent bacterial mastitis. Small Rumin Res. 88:119-125.

Nurhayati, I.S. dan E. Martindah. 2015. Pengendalian Mastitis Subklinis melalui Pemberian Antibiotik Saat Periode Kering pada Sapi Perah. Wartazoa. 25(2): 065-074. 
Rohmah, I.L. 2012. Faktor-Faktor yang Mempengaruhi Praktik Manajemen Pemeliharaan Sapi Perah pada Peternakan Pemasok Susu Segar Industri Keju Di Kabupaten Sukabumi [skripsi]. Institut Pertanian Bogor.

Sani Y, Indraningsih, S. Muharsini, dan M.I. Cahyono. 2011. Pengendalian mastitis dalam rangka recovery produksi susu sapi perah pasca-erupsi Gunung Merapi di Provinsi DIY dan Jawa Tengah. Laporan akhir Litkajibangrap Merapi. Balitbangtan. Jakarta (Indonesia).

Setiawan H., P. Trisunuwati, dan D. Winarso. 2012. Kajian Sensitivitas dan Spesifisitas Reagen CMT, WST dan SFMT Sebagai Bahan Uji Mastitis Subklinis di Peternakan Sapi Perah Rakyat, KUD Sumber Makmur Ngantang. [JURNAL]. Malang: Program Studi Pendidikan Dokter Hewan, Universitas Brawijaya.

Sudarwanto, M. dan E. Sudarnika. 2008. Hubungan antara $\mathrm{pH}$ Susu dengan Jumlah Sel Somatik Sebagai Parameter Mastitis Subklinik. Media Peternakan. 31(2): 107 - 113.
Sudarwanto, M. dan E. Sudarnika. 2008. Nilai Diagnostik Tes IPB Mastitis Dibandingkan dengan Jumlah Sel Somatik dalam Susu. Departemen Ilmu Penyakit Hewan dan Kesehatan Masyarakat Veteriner Fakultas Kedokteran Hewan Institut Pertanian: Bogor.

Surjowardojo, P. 2012. Penampilan Kandungan Protein Dan Kadar Lemak Susu Pada Sapi Perah Mastitis Friesian Holstein. 2(1), pp.42-48.

Winata, F. 2011. Hubungan antara penggunaan metode breed dengan uji mastitis IPB-1 untuk diagnosa mastitis subklinis [skripsi]. Bogor: Fakultas Kedokteran Hewan, Institut Pertanian Bogor.Wright T. 2007. Water quality for dairy cattle. Factsheet:410.

Xia, Stephen S. 2006. The rheology of gel formed during the California Mastitis Test. Thesis. The University of Waikato. 